\title{
Omalizumab as a Succesfull Therapy in Normocomplementemic Urticarial Vasculitis: A Series of Four Patients and Review of the Literature
}

\author{
Ece Nur Degirmentepe, Kubra Kızıltac, Pırıl Etikan, Ralfi Singer, Bachar Memet, Emek Kocaturk \\ Department of Dermatology and Venereology, Okmeydanı Training and Research Hospital, Istanbul, Turkey
}

Urticarial vasculitis is an eruption characterized by inflamed itchy or painful red papules or plaques that resemble urticaria but last longer than 24 hours and heal with residual pigmentation or purpura. Histopathologically, urticarial vasculitis presents as leukocytoclastic vasculitis with perivascular infiltrate and fibrin deposits. The treatment options are oral antihistamines, oral corticosteroids, dapsone, colchicine and hydroxychloroquine. We report four cases with normocomplementemic urticarial vasculitis who were treated with omalizumab and a brief review of the literature on the use of omalizumab in normocomplementemic urticarial vasculitis.

(Ann Dermatol 31(3) 335 338, 2019)

-Keywords-

Omalizumab, Urticarial vasculitis

\section{INTRODUCTION}

Urticarial vasculitis (UV) is a clinicopathological entity that is characterized by the coexistence of urticaria with

Received March 23, 2018, Revised June 5, 2018, Accepted for publication June 10, 2018

Corresponding author: Ece Nur Degirmentepe, Department of Dermatology and Venereology, Okmeydanı Training and Research Hospital, Kaptanpasa Mah. Darülaceze Cad. No: 27, 34384 Okmeydanı-Șişli, Istanbul, Turkey. Tel: 90-212-315-55-55, Fax: 90-212-221-78-00, E-mail: ecenuryksel@ gmail.com

ORCID: https://orcid.org/0000-0001-9596-2955

This is an Open Access article distributed under the terms of the Creative Commons Attribution Non-Commercial License (http://creativecommons. org/licenses/by-nc/4.0) which permits unrestricted non-commercial use, distribution, and reproduction in any medium, provided the original work is properly cited.

Copyright (c) The Korean Dermatological Association and The Korean Society for Investigative Dermatology leukocytoclastic vasculitis, perivascular infiltrate of lymphocytes, neutrophils and eosinophils, as well as fibrin deposits that are histopathologically typical features of leukocytoclastic vasculitis ${ }^{1}$. Symptoms of UV are frequently pain and burning rather than itching and resolve with persistent hyperpigmentation. UV can be classified into normocomplementemic UV (NUV) and hypocomplementemic UV (HUV) depending on the levels of complement protein in blood. Recommended treatments for UV are oral antihistamines $(\mathrm{OAH})$ and systemic immunosuppressant drugs such as oral corticosteroids, colchicine, dapsone and hydroxychloroquine ${ }^{2,3}$. Omalizumab is a recombinant humanized monoclonal anti-immunoglobulin (Ig)E antibody that has been approved for the treatment of chronic urticaria. There have been recent reports on the use of omalizumab for the treatment of $U^{2,4-7}$.

Here we describe four cases of UV treated with omalizumab with persuasive results. We also review previous reports of patients with $U V$ treated with omalizumab.

\section{CASE REPORT}

\section{Case 1}

A 41-year-old female patient presented with pruritic and painful skin rash typical of urticaria on her upper and lower extremities for the last year. The lesions were erythematous infiltrated wheals lasting for longer than 24 hours that resolved with postinflammatory hyperpigmentation (Fig. 1). Histopathologic examination of the skin revealed leukocytoclastic vasculitis (Fig. 2). The patient was treated with $\mathrm{OAH}$ for a month without improvement which was then followed by colchicine $0.5 \mathrm{mg}$ three times a day. After three months, the patient experienced relapse of skin rashes and was then treated with hydroxychloroquine 200 mg twice daily for three months without significant im- 
provement and switched to dapsone $50 \mathrm{mg}$ twice a day. After unsuccessfull treatment with dapsone for 8 months, omalizumab 300 mg subcutaneously (s.c.) once every four weeks was initiated. After the first application, complete remission of the UV was achieved with a urticaria control test (UCT) score of 16 . The patient is still under treatment with omalizumab $300 \mathrm{mg}$ s.c. every four weeks with sustained remission and no apparent adverse effect after 8 injections. We received the patient's consent form about publishing all photographic materials.

\section{Case 2}

A 34-year-old female patient with a 2-year history of UV was previously treated with $\mathrm{OAH}$ for at least 6 months without improvement. Oral prednisone $16 \mathrm{mg} /$ day had achieved remission but with early relapse after drug cessation. After colchicine $1.5 \mathrm{mg} /$ day started, the condition had worsened. Omalizumab $300 \mathrm{mg}$ s.c. once every four weeks was initiated which provided complete remission of the UV after the first injection and UCT scored as 15.

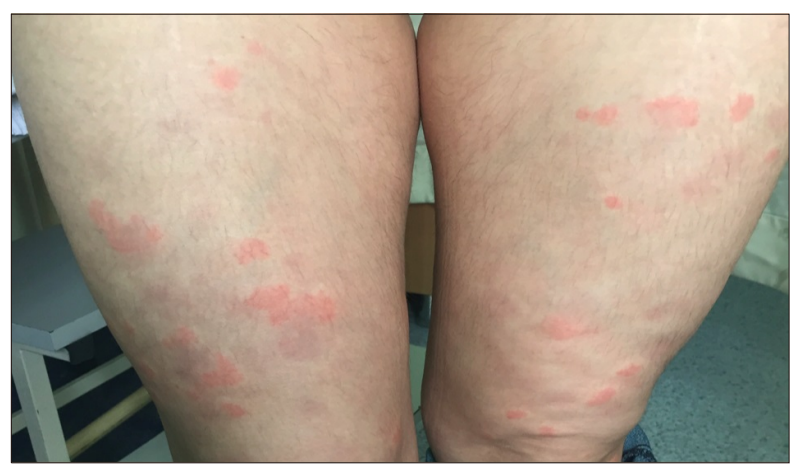

Fig. 1. Urticarial plaques and residual hyperpigmentation on the legs.
She remained stable after 12 injections of omalizumab $300 \mathrm{mg}$ monthly and the treatment switched to omalizumab 300 mg per 6 weeks. The patient is still under treatment with sustained remission.

\section{Case 3}

A 26-year-old male patient with a 3-year history UV was previously treated with $\mathrm{OAH}$ at least 6 months without improvement which was then followed by cyclosporine 100 mg twice a day. After one month of cyclosporine treatment, the patient experienced exacerbation of skin lesions. Omalizumab 300 mg s.c. once every four weeks was initiated which provided complete remission of the UV after the first application and UCT scored as 16. The patient is still under treatment with omalizumab $300 \mathrm{mg}$ s.c. every four weeks with sustained remission after 14 injections.

\section{Case 4}

A 58-year-old female patient with one-year history of UV,

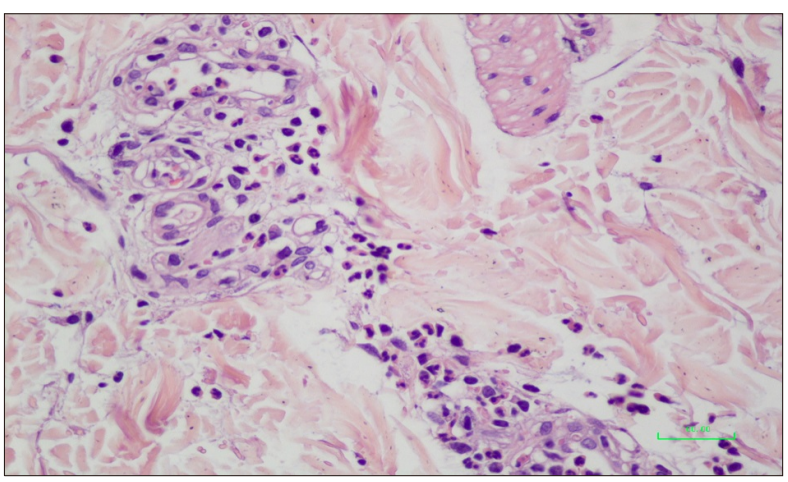

Fig. 2. Thickening in the vein walls and perivascular inflammatory cell infiltration, leukocytoclasia and fibrin accumulation $(\mathrm{H} \& \mathrm{E}, \times 400)$.

Table 1. Patients characteristics, histopathological and laboratory examination and treatment

\begin{tabular}{|c|c|c|c|c|c|c|c|c|c|c|c|}
\hline $\begin{array}{c}\text { Case } \\
\text { no. }\end{array}$ & $\begin{array}{l}\text { Age } \\
(y r)\end{array}$ & Sex & $\begin{array}{l}\mathrm{DD} \\
(\mathrm{mo})\end{array}$ & $\begin{array}{l}\text { Angio- } \\
\text { edema }\end{array}$ & Biopsy & DIF & $\mathrm{C} 3$ & ANA & Previous drugs $(\mathrm{mg} / \mathrm{d})$ & $\mathrm{NOI}$ & $\begin{array}{l}\text { TCR } \\
\text { (wk) }\end{array}$ \\
\hline 1 & 41 & $\mathrm{~F}$ & 12 & No & LV & $\mathrm{N} / \mathrm{A}$ & $\mathrm{N}$ & $(-)$ & $\begin{array}{l}\text { Rupatadin } 10 \\
\text { Colchicine } 1.5 \\
\text { Hydroxychloroquine } 400 \\
\text { Dapsone } 100\end{array}$ & 8 & 4 \\
\hline 2 & 34 & $\mathrm{~F}$ & 24 & Yes & LV & Positive $\mathrm{C} 1 \mathrm{q}+$ & $\mathrm{N}$ & $(-)$ & $\begin{array}{l}\text { Cetirizin } 10 \\
\text { Prednisone } 16 \\
\text { Colchicine } 1.5\end{array}$ & 12 & 4 \\
\hline 3 & 26 & $M$ & 36 & Yes & LV & $\mathrm{N} / \mathrm{A}$ & $\mathrm{N}$ & $(-)$ & $\begin{array}{ll}\text { Levocetirizin } & 5 \\
\text { Cyclosporine } 200\end{array}$ & 14 & 4 \\
\hline 4 & 58 & $\mathrm{~F}$ & 12 & Yes & LV & Positive $\mathrm{C} 3+\mathrm{C} 1 \mathrm{q}+$ & $\mathrm{N}$ & $(-)$ & Ebastine 10 & 5 & 4 \\
\hline
\end{tabular}

DD: duration of disease, DIF: direct immunofluorescence examination, ANA: antinuclear antibody, NOI: number of omalizumab injections, TCR: time to complete response, F: female, M: male, LV: leukocytoclastic vasculitis, N/A: nonavailable, N: normal. 
was previously treated with $\mathrm{OAH}$ at least 6 months without improvement. According to our previous experiences with UV, the patient was started on omalizumab $300 \mathrm{mg}$ s.c. every four weeks. After the first application, complete remission of the UV was achieved and UCT score increased from 3 to 12 . The patient is still treated with omalizumab 300 mg s.c. every four weeks with sustained remission after 5 injections.

The diagnosis of UV in all of the above cases was made based on the clinical, histopathological and direct immunofluorescence examination findings (Table 1).

\section{DISCUSSION}

UV is a leukocytoclastic vasculitis with wheals that resemble urticaria but last more than 24 hours. It represents a continuum of disease, ranging from urticaria with minimal vasculitis, to life- or organ-threatening systemic vasculitis with minimal urticaria ${ }^{8}$.

UV can be divided into NUV and HUV depending on the levels of complement protein in blood. HUV has systemic manifestations such as angioedema, arthralgia, fever, abdominal or thoracic pain, renal or pulomonary disease, episcleritis and uveitis ${ }^{1}$. NUV usually presents with less systemic symptoms and without underlying diseases therefore are considered as idiopathic ${ }^{9}$. NUV might also be considered as urticaria showing signs of vasculitis in histopathology because in a series of 83 patients with chronic urticaria 10 exhibited histologic features of $U V^{10}$.

Omalizumab has been designed to recognise and attach to a specific structure (C3 domain) on circulating human $\operatorname{lgE}$. This prevents IgE binding to high affinity receptors (Fc $\varepsilon \mathrm{RI}$ ) on the surface of mast cells and basophils, thus reducing inflammatory cell activation including B- cells. It also causes eosinophil apoptosis, increases interleukin (IL)-2, IL-3, interferon-gamma and tumor necrosis factor-alpha and reduces IL-4. The mechanism of action of omalizumab in UV is not fully understood, it may be associated with downregulation of $F c \varepsilon R I$ receptors and supression of proinflammatory cytokines and therefore interfering the generation of urticarial wheals. Blocking anti-lgG IgEs which are responsible for the development of immune complexes on the vessel walls may also be considered as a possible mechanism of action. In summary, omalizumab may be effective in UV through its reduction of IgE and chemotaxis and immune complex formation ${ }^{11-14}$. The complement levels in our patients were normal, therefore they are considered as NUV. The efficacy of omalizumab in these patients is not unexpected when we consider NUV as "urticaria with minimal vasculitis."

HUV syndrome (HUVS) is a rare immune complex medi- ated disease which has distinct pathophysiology and outcomes. Aurich et al. ${ }^{15}$ reported that omalizumab is not effective in HUVS. This suggests the pathophysiology of HUVS is significantly different from chronic spontaneous urticaria (CSU) and NUV.

Omalizumab has been shown to be effective on the symptoms of UV in case reports but there are no prospective clinical studies of omalizumab for UV (grade D recommendation) ${ }^{2,4-7,16}$. A case report by Ghazanfar and Thomsen ${ }^{2}$ described a male patient with UV who failed to respond to oral prednisolone and dapsone therapy. He was then treated with omalizumab 300 mg once every four weeks and after one month a complete remission of the disease and symptoms were observed. Ramírez Del Pozo et al. ${ }^{4}$ reported a female patient with UV and systemic lupus erythematosus. The patient was unresponsive to $\mathrm{OAH}$, oral corticosteroids and azathioprine and was started on omalizumab which provided a rapid relief of symptoms. Another case report by Varricchi et al. ${ }^{5}$ described a female patient with Churg-Strauss syndrome, asthma and UV. She was treated with $\mathrm{OAH}$, oral corticosteroids and immunosuppressants such as azathioprine and cyclosporine without improvement. She was then administrated omalizumab 300 mg s.c. every two weeks as an addition to her pre-treatments. The patient reported a significant improvement after 6 months of treatment with omalizumab. A case report from Spain describing three female patients with CSU difficult to control with associated vasculitis noted that omalizumab was a successful treatment option for the patients in the study ${ }^{6}$. Lately, Fueyo-Casado et al. ${ }^{7}$ reported a female patient with ten year history of chronic recurrent UV. She was treated with $\mathrm{OAH}$ at least 6 months, oral prednisolone and oral cyclosporine without improvement. Dapsone and antileucotrienes had only been minimally effective. She was then started omalizumab $300 \mathrm{mg}$ s.c. every 4 weeks which showed clinical improvement within the firsth month and complete remission within the fifth month.

Omalizumab $300 \mathrm{mg}$ per a month provided symptom control in our cases within one month with a notable increase in UCT scores. Some authors use $300 \mathrm{mg}$ per a month and others $300 \mathrm{mg}$ per 6 weeks but there is no consensus on the dose and intervals; but applying the same dose and interval scheme as CSU seems rationale.

Our report is important because we noted complete remission of the UV lesions within one month. It shows that mechanism of action of omalizumab in NUV may be similar to its mechanism of action in CSU.

As many patients with UV experience major side effects of the standard treatment and cannot be treated successfully, omalizumab gives us promising results with its safety pro- 
file in the treatment of NUV.

In conclusion, omalizumab may be useful in the treatment of vasculitic urticaria, especially with normal complement levels. This observation needs to be validated with prospective, randomized, placebo-controlled trials.

\section{CONFLICTS OF INTEREST}

The authors have nothing to disclose.

\section{ORCID}

Ece Nur Degirmentepe, https://orcid.org/0000-0001-9596-2955 Kubra Kızıltac, https://orcid.org/0000-0003-0741-1067

Pırıl Etikan, https://orcid.org/0000-0002-0513-8020

Ralfi Singer, https://orcid.org/0000-0002-1395-5960

Bachar Memet, https://orcid.org/0000-0001-7731-943X

Emek Kocaturk, https://orcid.org/0000-0003-2801-0959

\section{REFERENCES}

1. Kocatürk E. Differential diagnosis in urticaria: urticarial vasculitis, neutrophilic urticarial dermatosis and urticarial dermatitis. Turk Klinikleri J Dermatol-Special Top 2015;8: 26-33.

2. Ghazanfar MN, Thomsen SF. Omalizumab for urticarial vasculitis: case report and review of the literature. Case Rep Dermatol Med 2015;2015:576893.

3. Moreno-Suárez F, Pulpillo-Ruiz Á, Zulueta Dorado T, ConejoMir Sánchez J. Urticarial vasculitis: a retrospective study of 15 cases. Actas Dermosifiliogr 2013;104:579-585.

4. Ramírez Del Pozo ME, Martínez Saenz NP, Vera JG, Tiro JL. 274 vasculitic urticaria treated with omalizumab. Case report. World Allergy Organ J 2012;5(Suppl 2):S106.

5. Varricchi G, Detoraki A, Liccardo B, Spadaro G, de Paulis A, Marone G, et al. 275 efficacy of omalizumab in the treatment of urticaria-vasculitis associated to Churg-Strauss Syn- drome: a case report. World Allergy Organ J 2012;5(Suppl 2):S106-S107.

6. Díez LS, Tamayo LM, Cardona R. [Omalizumab: therapeutic option in chronic spontaneous urticaria difficult to control with associated vasculitis, report of three cases]. Biomedica 2013;33:503-512. Spanish.

7. Fueyo-Casado A, Campos-Muñoz L, González-Guerra E, Pedraz-Muñoz J, Cortés-Toro JA, López-Bran E. Effectiveness of omalizumab in a case of urticarial vasculitis. Clin Exp Dermatol 2017;42:403-405.

8. Brewer JD, Davis MDP. Urticarial vasculitis. Waltham: UpToDate [cited 2017 Nov 5]. Available from: https://www. uptodate.com/contents/urticarial-vasculitis.

9. Wisnieski JJ. Urticarial vasculitis. Curr Opin Rheumatol 2000;12:24-31.

10. Zuberbier T, Maurer M. Urticarial vasculitis and Schnitzler syndrome. Immunol Allergy Clin North Am 2014;34:141147.

11. Maurer M, Rosén K, Hsieh HJ, Saini S, Grattan C, GimenézArnau $A$, et al. Omalizumab for the treatment of chronic idiopathic or spontaneous urticaria. N Engl J Med 2013; 368:924-935.

12. Kaplan A, Ledford D, Ashby M, Canvin J, Zazzali JL, Conner $\mathrm{E}$, et al. Omalizumab in patients with symptomatic chronic idiopathic/spontaneous urticaria despite standard combination therapy. J Allergy Clin Immunol 2013;132:101-109.

13. Zuberbier $T$, Aberer W, Asero R, Bindslev-Jensen C, Brzoza $\mathrm{Z}$, Canonica GW, et al. The EAACl/GA(2) LEN/EDF/WAO Guideline for the definition, classification, diagnosis, and management of urticaria: the 2013 revision and update. Allergy 2014;69:868-887.

14. Kaplan AP, Giménez-Arnau AM, Saini SS. Mechanisms of action that contribute to efficacy of omalizumab in chronic spontaneous urticaria. Allergy 2017;72:519-533.

15. Aurich S, Simon JC, Treudler R. Omalizumab does not improve skin lesions in a patient with hypocomplementemic urticarial vasculitis syndrome. J Eur Acad Dermatol Venereol 2017;31:e395-e397.

16. Chia JC, Mydlarski PR. Dermatologic uses of omalizumabtitle. J Dermatolog Treat 2017;28:332-337. 